\section{Iranian EFL teachers and learners' beliefs about vocabulary learning and teaching}

\author{
Amiryousefi, Mohammad \\ University of Isfahan, Iran (M.Amiryousefi@yahoo.com)
}

Received: 2 December 2014

Available Online: 25 February 2015

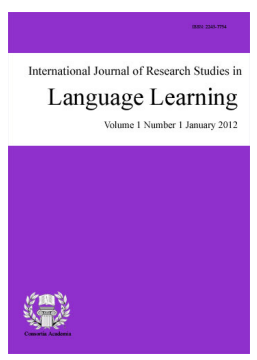

Accepted: 2 February 2015
ISSN: 2243-7754 Online ISSN: 2243-7762

OPEN ACCESS

\begin{abstract}
Teachers and students' beliefs about different aspects of language learning and teaching affect their decisions, actions, teaching and learning and form their expectations and judgments about what works and what does not. If classroom activities and procedures are in line with their beliefs, they will be motivated and get involved. Otherwise, there will be a clash between the teachers and the students or the teachers and the administrators. Vocabulary is also at the heart of developing communicative language proficiency and building meaningful interactions. The present study aimed at exploring the Iranian EFL teachers and learners' beliefs about vocabulary learning and teaching. The required data were elicited by the use of a five-point liker scale questionnaire which was given to 292 EFL teachers and learners. The results showed that in the Iranian EFL teachers and learners' opinions: a) vocabulary and grammar have equal importance, b) both vocabulary knowledge and vocabulary use are important, c) vocabulary should be taught directly to the students at all levels, d) the use of new technologies, pictures and videos are helpful in vocabulary learning and teaching and e) dictionaries can help vocabulary learning and students at all levels must be encouraged and taught to use monolingual dictionaries.
\end{abstract}

Keywords: beliefs; vocabulary importance; vocabulary learning and teaching; dictionary use; new technologies 


\section{Iranian EFL teachers and learners' beliefs about vocabulary learning and teaching}

\section{Introduction}

Vocabulary is sometimes sidelined in the area of language teaching and learning due to a common shibboleth that an adequate knowledge of grammar along with some reading proficiency are the only elements needed by the students (Baleghizadeh \& Golbin, 2010). This belief has made some English teachers in countries like Iran focus greatly on grammatical rules and structure, disregard the role of vocabulary and turn it into a Cinderella element. Milton (2009) believes that the neglect of vocabulary can be traced in: 1) the structural approaches to language learning and teaching that emphasize the acquisition of rules and systems. For them vocabulary is unchallenging and unsystematic and is not a good target for language learning and teaching, 2) the beliefs among teachers and administrators that it is even possible to become a proficient and sophisticated language user with limited number of words and 3) the widely held belief that explicit vocabulary teaching is a waste of time and most of vocabulary is learned incidentally by osmosis from the language which surrounds learners inside or outside the class. There are, on the other hand, researchers who strongly believe that vocabulary is an important part of language which is central to the development of other language skills and language proficiency, and an inadequate knowledge of vocabulary will act as an obstacle in using that language (Schmitt, 2010; Alderson, 2005). Schmitt (2010), for example, believes that meaningful communication in a foreign language depends mostly on words. If learners do not have the available words to express their ideas, mastering grammatical rules or pronunciation does not help.

Beliefs are also very powerful in human beings' behavior and lives. Beliefs can make human beings love and live or hate and fight with each other (Fisherbein \& Ajzen, 1975; Ajzen, 1988; Bernat \& Gvozdenko, 2005). In educational contexts, based on the social cognitive theory (Kitsantas \& Zimmerman, 2009; Bembenutty \& White, 2013), students and teachers' decisions, actions, functioning and learning are shaped by the beliefs they bring with them. Teachers and students usually act on what they believe is good and right. The effects of beliefs are even bigger than the effects of methodological instructions, and what students and teachers do is governed by their beliefs (Li \& Walsh, 2011). Brown (2014) also believes that teachers and educational administrators should try to raise their awareness about what works and what does not work in the classroom. Considering the importance of vocabulary in language learning and the role of students and teachers' beliefs, it would be a good idea to explore teachers and students' beliefs about different aspects of vocabulary learning and teaching.

\subsection{Importance of vocabulary}

Vocabulary is believed to be at the heart of learning another language without which building a meaningful communication would be rather impossible (Schmitt, 2010). This fact is known by language learners, and it is for this reason that they usually carry vocabulary books and notebooks rather than grammar ones (Schmitt, 2010, 2000). Knight (1994) and Laufer and Hulstijin (2001) also observed that vocabulary is considered as number one priority by language learners and teachers, and language learning involves the acquisition of a huge number of vocabulary items. Moreover, second language learners are often conscious of the extent to which limitations in their vocabulary knowledge hamper their ability to communicate successfully in the target language which gives vocabulary learning a salience for learners that may be lacking in the acquisition of other features of the language (Read, 2004). Vocabulary is also viewed as a core component of language proficiency which provides much of the basis for how well language learners listen, speak, read, and write (Richards \& Renandya, 2002).

Other researchers (Jones, 1995; Bores \& Lindstromberg, 2008; Folse, 2004) even believe that what learners need to do in order to learn a language is to make a working extensive vocabulary without which they would achieve less than their potentials and may not try to use language learning opportunities which are 
Iranian EFL teachers and learners' beliefs about vocabulary learning and teaching

around them such as talking to native speakers, watching English programs, etc.

Vocabulary is also considered as the cornerstone of literacy and when people think of language they almost always think of words (Beck \& McKeown, 1985; Stubbs, 1986). Alderson (2005) upon his examination of the relation between vocabulary and language skills through DIALANG test found a very strong relationship between all language skills and vocabulary, and concluded that "what [the DIALANG analysis] would appear to show is that the size of one's vocabulary is relevant to one's performance on any language test, in other words, that language ability is to quite a large extent a function of vocabulary size"(p. 88). Benjamin and Crow (2010) even believe that vocabulary is the center of all classes not just language classes. Finally, Ellis (1999) provides two good reasons to focus on vocabulary. First, vocabulary development is now recognized by both researchers and learners as a major aspect of learning a new language. Second, vocabulary acquisition is an important area that is easier to investigate than the acquisition of grammatical or pragmatic knowledge.

\subsection{Importance of teachers and students' beliefs}

Despite its popularity, the term belief has not received a consistent and unified definition yet. Various authors and researchers (Kuntz, 1996; Banya \& Cheng, 1997; White, 1999; Borg, 2001) have defined the term differently. Kuntz (1996), for example, believes that a belief consists of notions about what language is and how it is learned. Banya and Cheng (1997) also believe that opinions about how language is learned can be called beliefs. White (1999) believes that world is seen and understood through the lens of beliefs and beliefs play an instrumental role in defining classroom behavior. He even believes that people's understanding of themselves is shaped by their beliefs. Borg (2001), on the other hand, presents a more comprehensive definition for belief. He believes that a belief can be either conscious or unconscious, is accepted as truth by people and, therefore, brings emotive commitment with it and guides thoughts, behavior and functioning. Based on this definition, it can be concluded that students and teachers do not invest their efforts and energy on unless something is in line with their beliefs. In the same fashion, Riley (2009) based on the fundamental assumptions proposed by Pajares (1992) about the nature and the role of beliefs states that:

$>\quad$ Beliefs are formed early, through a process of cultural transmission, and tend to self-perpetuate, persevering even against contradictions caused by reason, time, schooling, or experience.

$>\quad$ The earlier a belief is incorporated into the belief structure, the more difficult it is to alter. Belief change during adulthood is a relatively rare phenomenon.

$>\quad$ Beliefs are instrumental in defining tasks and selecting the cognitive tools with which to interpret, plan, and make decisions regarding tasks. Beliefs strongly affect an individual's behavior (Pajares, 1992, p. 103).

Research also suggests that beliefs heavily influence teachers and students' pedagogical practices in the classroom (Borg, 2003; Ng \& Farrell, 2003; Mangubhai et al., 2004; Horwitz \& Gregersen, 2002; Riley, 2009; Mohebi \& Khodadadi, 2011). Riley(2009), for example, believes that language learners have beliefs about the nature of language and language learning which are formed based on their attitudes, experiences and expectations. Differences in beliefs can make language learners approach learning tasks differently despite their similarities in language proficiency. Beliefs are also considered to have effects on students' personal attributes such as anxiety and motivation and are the cause of individual differences in educational settings (Horwitz \& Gregersen, 2002; Mohebi \& Khodadadi, 2011). Students' beliefs can be both realistic and unrealistic which need to be addressed appropriately by the teachers to form a supportive and cooperative environment in the classroom (Riley, 2009). Understanding learners' beliefs are, consequently, of utmost importance because through understanding the beliefs, teachers can raise their awareness about their students' expectations and approaches to language learning and then try to correct those beliefs which are inaccurate and unrealistic and to plan their instructions based on those which are realistic and accurate (Mohebi \& Khodadadi, 2011). Otherwise, there will 
be mistrust and reluctance on the part of the students and ultimately a breakdown in learning (Riley, 2009).

Teachers' beliefs are also strong predictors of their decisions and classroom practices. Nation and Macalister (2010) believe that what teachers do is determined by their beliefs. In the same vein, Williams and Burden (1997) state that "teachers' deep-rooted beliefs about how languages are learned will pervade their classroom actions more than a particular methodology they are told to adopt or course book they follow" (p. 57). Likewise, Kagan (1992) states that teacher' instructions and practices reflect their beliefs about language learning and teaching. Borg (2003), on the other hand, notes that teachers are considered as experts by their students because they are active agents in educational contexts who make instructional decisions and choices based on their knowledge, thoughts and beliefs. They can, consequently, affect their students' beliefs (Riley, 2009). Riley (2009) further believes that if teachers and students' beliefs are consistent with each other learning is enhanced, otherwise there will be a clash between the teachers and the students. Understanding teachers' beliefs about different aspects of language learning and teaching is also of crucial importance.

There are a number studies cited in the literature (Tran, 2011; Macalister, 2012; Augustyn, 2013) which explored EFL teachers and learners' beliefs about different aspects of vocabulary learning and teaching. Tran, for example, explored Vietnamese teachers' beliefs about vocabulary learning and teaching by the use of a questionnaire. The results of the study showed that the participants believed that reading is a powerful method to increase vocabulary and technology can greatly help learners to learn vocabulary elements. They also believed that strategies like guessing the meaning of the unknown words can be really helpful. Macalister (2012), on the other hand, examined the beliefs of Malaysian pre-service teachers about vocabulary teaching. His examination revealed that the participants held beliefs that coincided with those of their trainers to some extent. Augustyn, (2013) also explored the current practices and beliefs about vocabulary teaching and learning in typical communicative-approach German classrooms. He found out that by integrating translation and extensive reading core vocabulary elements can be taught and learned easily in introductory levels. The present study, however, aims at exploring and comparing the Iranian EFL learners and teachers' beliefs about different aspects of vocabulary learning and teaching.

\subsection{The purpose of the present study}

The theoretical framework of the present study is informed by the fact that teachers and students' beliefs play an important role in determining their actions, functioning, learning and teaching. These beliefs can ,even better than the existing theories of language learning and teaching, provide us with a framework for understanding how language teachers and learners conceptualize learning and teaching and how they make use of the learning and teaching situations around them (Breen, 2001). Vocabulary is also an important component of language learning without which learners cannot use their learning opportunities and build meaningful interactions. Considering these issues and the above-mentioned preliminaries, the present study attempts to explore the Iranian EFL learners and teachers' beliefs about different aspects of vocabulary teaching and learning. It, therefore, addresses the following questions:

$>\quad$ What do the Iranian EFL learners and teachers think about the importance of vocabulary in English language learning?

$>\quad$ What are their beliefs about vocabulary learning and teaching?

$>\quad$ What do they think about the use of new technologies in vocabulary learning and teaching?

$>\quad$ What do they think about the role of dictionaries in vocabulary learning? 


\section{The study}

\subsection{Participants}

The sample of the study included 292 participants comprising 224 students and 68 English teachers. The participants of the study were the teachers and language learners of Iran Language Institute and ACECR English institute (I.U.T. Branch), two famous English institutes in Isfahan, Iran. The students participated in this study were learning English in different levels from elementary to advance at the adults' department in the spring semester of 2014. Their age ranged from 14 to 39, and their degrees ranged from high school diploma to Ph.D. The majority of the teachers were also female. Their age ranged from 25 to 47 and they had different degrees in English from B.A. to Ph.D. Table1 shows the characteristics of the participants of the study.

\section{Table 1}

The Participants' Characteristics

\begin{tabular}{lll}
\hline & \multicolumn{1}{c}{ Teachers } & \multicolumn{1}{c}{ Students } \\
\hline Number & 68 & 224 \\
Male & 43 & 85 \\
Female & 25 & 139 \\
Age & $25-47$ & $14-39$ \\
Education & B.A to Ph.D. & Diploma to Ph.D. \\
\hline
\end{tabular}

\subsection{The questionnaire}

The required data were elicited by the use of a five-point likert scale questionnaire which was adopted from Tran (2011) developed to study the Vietnamese teachers' beliefs about vocabulary learning and teaching. The original questionnaire contained 68 four-point Likert-scale items which were divided into four main parts, namely: a) the role of vocabulary in English language learning (6 items), b) the role of vocabulary learning strategies in language learning (5 items), c) beliefs about vocabulary learning and teaching (39 items), and d) the role of dictionaries in language learning (18 items). It was, however, modified and changed based on the studies done in the literature (Gu \&Johnson, 1996; Kim, 2008) and the nature of the present study. Some items were omitted, some were reworded and some new items were added to the list. The organization and the division of the questionnaire were also changed.

The questionnaire used in the study comprised 61 response categories which were evaluated by the participants based on the anchor points of $1=$ "strongly disagree," $2=$ "disagree," $3=$ "no idea", 4= "agree," and 5 ="strongly agree". The questionnaire was divided into four major parts: 1) the importance of vocabulary in English language learning (8 items); 2) beliefs about vocabulary learning and teaching (30 items), 3) beliefs about the use of new technologies in vocabulary learning and teaching ( 5 items) and 4 ) the role of dictionaries in language learning (18 items). To minimize the measurement errors (Brown, 2001), the questionnaire was translated into Farsi, the participants' native language.

The final format was reviewed by 7 experienced teachers and scholars and necessary changes were made. To explore its reliability, it was given to a group of 36 English teachers and 53 English learners which were comparable to the participants of the study and the following results were obtained. As shown in table $3, \alpha$ is bigger than 0.7 for both the students and the teachers which shows the reliability of the instrument used.

\section{Table 2}

The Reliability Statistics of the Questionnaire

\begin{tabular}{lcc}
\hline Position & Cronbach's Alpha & N of Items \\
\hline Teachers & 0.769 & 65 \\
Students & 0.748 & 64 \\
\hline
\end{tabular}


To check the validity of the questionnaire, factor analysis with varimax rotation was also employed. As shown in table2, the $\mathrm{KMO}$ is bigger than $0.6(\mathrm{KMO}=0.679>0.6)$ which shows that the 64 strategies fit into the four main factors hypothesized.

\section{Table 3}

The Results of KMO and Bartlett's Test

\begin{tabular}{lll}
\hline Kaiser-Meyer-Olkin Measure of Sampling Adequacy. & .676 \\
Bartlett's Test of & Approx. Chi-Square & 3.690 \\
Sphericity & df & 2278 \\
& Sig. & .000 \\
\hline
\end{tabular}

After getting the necessary permissions and observing the related ethical issues, the participants were given 35 minutes to complete the questionnaire during class time preceded by a brief explanation of the purpose and nature of the study. The participants were asked to read the questionnaire through and evaluate each statement based on the choices available. After the completion of the instrument, the questionnaires were collected by the researcher for data analysis.

\section{Results}

The data were prepared for analysis and then analyzed using the Statistical Package for the Social Sciences (SPSS) version 16. Then the frequency of the responses to each part of the questionnaire was analyzed separately for the teachers and the students. The results related to each research question are separately presented in the following parts.

\subsection{The importance of vocabulary}

As mentioned earlier, this part contained 8 items exploring the participants' beliefs about the importance of vocabulary in English learning in general and the development of each skill in particular. The majority of the teachers (around 96.8\%) and the students (around 96.2\%) agreed that it is important to learn enough words if language learners want to learn English effectively. The majority of them (around $67 \%$ of the students and $73 \%$ of the teachers) also believed that vocabulary plays an important role in building a meaningful communication and developing speaking (around $67 \%$ of the students and $73 \%$ of the teachers), listening (around $67 \%$ of the students and $64 \%$ of the teachers), reading (around $86 \%$ of the students and $72 \%$ of the teachers) and writing (around $53 \%$ of the students and $64 \%$ of the teachers) skills. The highest rate belongs to the importance of vocabulary in reading comprehension while the lowest rate belongs to its importance in writing proficiency. The majority of them (around $53 \%$ of the students and $67 \%$ of the teachers), on the other hand, did not agree that vocabulary is more important than grammar. They (around $89 \%$ of the students and $87 \%$ of the teachers) believed that vocabulary and grammar have equal importance in English learning.

\subsection{Beliefs about vocabulary learning and teaching}

As to the second part of the questionnaire - what the participants think about different aspects of vocabulary teaching and learning- the available items were divided into two parts, namely items related to the teaching of vocabulary and items related to the learning of vocabulary. Regarding the importance of reading in vocabulary development, the majority of the students (around 84\%) and more than half of the teachers (around 52\%) agreed that reading is an excellent way to improve vocabulary but only less than half of the teachers and the students ( around 32\%) agreed that it is the only way through which vocabulary can be learned. As to the receptive and productive aspects of vocabulary knowledge, the majority of the teachers (around $81 \%$ ) believed that understanding vocabulary items in reading and listening (receptive aspect) is easier than using them in writing and speaking. However, half of the students agreed with their teachers and the rest either did not agree (around $35 \%$ ) or had no idea (around 19\%) in this regard. 
The ideas were also inconsistent about the effectiveness of word lists in vocabulary learning. About one fourth of the participants (around 20\% of the students and 25\% of the teachers) agreed with the statement that learning the new words through vocabulary lists is not very productive, about one third of them (around $31 \%$ of the students and $32 \%$ of the teachers) had no idea, and the rest (around $38 \%$ of the students and $42 \%$ of the teachers) disagreed with the statement and believed that it is effective to use word lists. With regard to learning the semantically related words and guessing the meaning of the unknown words, about $75 \%$ of the teachers and $73 \%$ of the students in the former and $90 \%$ of the teachers and $80 \%$ of the students in the latter believed that these techniques can enhance vocabulary learning.

The use of translation was not favored by the participants and the majority of them (around 80\%) believed that it should be avoided. The mechanical drills of memorization and repetition were not, however, equally rated. About $39 \%$ of the teachers and $50 \%$ of the students agreed with the memorization and $70 \%$ of the teachers and $85 \%$ of the students agreed with the repetition of vocabulary items as good ways to learn them. Therefore, the majority of the teachers did not consider memorization to be a useful practice. The majority of the participants (about $96 \%$ of the teachers and $88 \%$ of the students) also believed that frequent exposure to the words in reading, audio or video materials can be very effective in vocabulary learning. While $52 \%$ of the students had no idea about the usefulness of vocabulary notebooks, around $56 \%$ of the teachers agreed with it as a good way to learn vocabulary.

As to the participants' beliefs about when a word is learned, the majority of the students (about 72\%) agreed with the statement that a word is learned when its meaning is known. The majority of the teachers either did not agree (about $45 \%$ ) with it or had no idea (16\%). However, the majority of the participants (around $90 \%$ of the students and $96 \%$ of the teachers) agreed that when a word can be understood in reading and listening and used in writing and speaking it is learned. Also, about $68 \%$ of the students and $82 \%$ of the teachers believed that understanding a word and being able to use it are equally important and should be equally emphasized. Though, they (around $80 \%$ of the students and $83 \%$ of the teachers) believed that understanding a word should precede its use. As to the amount of time needed to be spent on vocabulary compared to grammar, about $58 \%$ of the students and $59 \%$ of the teachers believed that vocabulary needs more time.

There were also some items regarding the participants' beliefs about the preliminary aspects of vocabulary teaching. The first two items asked the participant which one, grammar or vocabulary, they believed must be taught to the beginners first. About $19 \%$ of the teachers and $16 \%$ of the students believed that grammar should come first, $45 \%$ of the teachers and $32 \%$ of the students believed that vocabulary should be taught first and around $40 \%$ of the students had no idea in this regard. Regarding vocabulary teaching, about $62 \%$ of the students and $66 \%$ of the teachers agreed that vocabulary must be taught directly to the students of all levels of proficiency and it should not be limited to the words that occur frequently.

Regarding the use of Farsi in vocabulary instruction, about $62 \%$ of the students and $60 \%$ of the teachers believed that words should be taught in English not in Farsi. They (about 60\% of the students and $67 \%$ of the teachers) believed that if Farsi is used in vocabulary instruction, learners' mind becomes lazy and they cannot use the words in their future communication. They (about $76 \%$ of the students and $67 \%$ of the teachers), however, believed that simple words and language must be used by the teachers when they teach new words. The last items in this part explored the participants' beliefs about vocabulary learning strategies. Around $80 \%$ of the students and $94 \%$ of the teachers believed that vocabulary learning strategies are very important for language learners, and about $73 \%$ of the students and $70 \%$ of the teachers agreed that they must be taught to the students at all levels. They (about $69 \%$ of the students and $71 \%$ of the teachers), however, did not agree that these strategies are learned naturally without being instructed by teachers.

\subsection{Beliefs about the use of multimedia and new technologies}

This part of the questionnaire contained some items that explored the participants' beliefs about the use of 
new technologies, multimedia and computer assisted language learning programs in vocabulary learning and teaching. About $68 \%$ of the students and $77 \%$ of the teachers believed that when words are presented with pictures they are learned better. Even 53\% of the students and 55\% of the teachers believed that videos are much better than pictures in this regard. They also valued the role of the internet and multimedia in vocabulary learning and around $70 \%$ of the students and $87 \%$ of the teachers believed that they are effective for vocabulary development. However, $63 \%$ of the students and $80 \%$ of the teachers believed that the existing technologies in English classes and institutes are inadequate and more technologies should be incorporated.

\subsection{Beliefs about the role of dictionaries}

Dictionaries have always been the issue of controversy in language classes especially in Iran. Whether to use a bilingual or a monolingual dictionary, to let the students use their dictionaries inside the class, etc. are the topics which form the heart of this debate. As to the role of dictionaries in vocabulary learning, $68 \%$ of the students and $90 \%$ of the teachers believed that dictionaries can improve English in general, and $74 \%$ of the students and $83 \%$ of the teachers believed that they can improve and facilitate vocabulary learning in particular. However, there was not an agreement among the teachers and the students whether dictionary use should be the first step to get the meaning of a new word. While $59 \%$ of the students agreed with it $62 \%$ of the teachers either disagreed or had no idea. They (62\% of the students and $68 \%$ of the teachers), however, believed that a dictionary must be used when the students cannot guess the meaning of a word. Also, 58\% of the students and $87 \%$ of the teachers believed that dictionaries should be used in class, and only $25 \%$ of the teachers and the students agreed with the statement that dictionary use in class causes the students not to listen to the teacher.

Regarding the use of bilingual or monolingual dictionaries, $60 \%$ of the students and $93 \%$ of the teachers believed that monolingual dictionaries are much better. They (68\% of the students and $87 \%$ of the teachers) also believed that students at all levels should be encouraged to use monolingual dictionaries. Even about $70 \%$ of the teachers disagreed with the statement that bilingual dictionaries should be used by beginners and elementary students. The students' position was somewhat different in this regard. About 33\% of them had their teachers' idea, about $27 \%$ of them had no idea and $40 \%$ of them agreed with the statement and believed that bilingual dictionaries are good for beginners and elementary students. The participants (about $89 \%$ of the students and $93 \%$ of the teachers), however, believed that students need to be taught how to use a dictionary properly.

\section{Conclusions}

Vocabulary was the Cinderella sister of grammar and other parts of language in the past. More recently, the scholars and researchers in the field have woken up to the idea that vocabulary is an important part of language which forms the basis of communicative proficiency and is the cornerstone of literacy (Schmitt, 2010, 2000; Alderson, 2005; Read, 2004; Richards \& Renandya, 2002). These scholars believe that vocabulary elements greatly affect the development of all language skills, and without sufficient number of words students cannot use the learning opportunities around them. These and other similar ideas have made vocabulary number one priority for language teachers and learners.

Moreover, beliefs play a pivotal role in human beings' lives. "Good", "bad", "appropriate", "inappropriate", etc. are the judgments which are usually made based on the beliefs people have (Bernat \& Gvozdenko, 2005). Beliefs also play a central role in education in general and in language learning in particular. Students and teachers' actions, decisions and behavior are determined by the beliefs they usually bring with them to educational settings (Ng \& Farrell 2003; Mangubhai et al., 2004; Maftoon, 2012). Examining students and teachers' beliefs about different aspects of language teaching and learning can, therefore, provide valuable information about what practices and tasks are considered useful by teachers and students to be included and what differences exist between their beliefs to be taken into account. In this connection, the present study was an endeavor to explore the Iranian EFL learners and teachers' beliefs about different aspects of vocabulary learning and teaching. 
Iranian EFL teachers and learners' beliefs about vocabulary learning and teaching

Based on the results of the present study, it can be inferred that for the Iranian EFL teachers and learners: 1) vocabulary is at the heart of developing communicative language proficiency and reading, writing, listening and speaking skills; 2) grammar and vocabulary have equal importance and equal time should be spent on them; 3) reading is an important medium through which vocabulary can be improved. It is not, however, the only way and vocabulary can be learned through other media too; 3 ) both aspects of vocabulary knowledge, namely receptive and productive aspects are important and a word is learned when it can be understood in reading and listening and can be used in speaking and writing; 4) repetition and guessing the meaning of the unknown words are very useful while translation and memorization should be avoided. Learning new words through word lists is not also welcomed and keeping a vocabulary notebook is not a popular activity; 5) grammar and vocabulary should be developed in concert with each other and words should be taught directly to the students at all levels. Vocabulary learning strategies are very important and they must form an important part of vocabulary instruction. Teachers ,however, need to use simple words and structures when they want to teach new words; 6) Farsi should not be used in vocabulary instruction because it makes students lazy and will not improve their communicative abilities; 7) technologies like the internet, computers, multimedia and videos can assist vocabulary learning and instruction. However, the existing technologies are not enough and satisfactory. More and newer technologies need to be incorporated; 8) dictionaries can improve vocabulary and can be used both inside and outside the classroom. Bilingual dictionaries should not be used and students at all levels should be encouraged and instructed to use monolingual dictionaries.

\subsection{Discussions and implications}

The results of the present study in line with the results of the studies done in the literature show that vocabulary is an important part of language which is highly esteemed by language learners. Textbook designers, lesson planners and teachers should, therefore, try to incorporate enough vocabulary items in their programs and materials and devote a part of their instruction to vocabulary and the related strategies. Otherwise, based on Riley (2009) there will be a clash between the teachers and the learners and failure and dissatisfaction will be experienced instead of motivation, involvement and success. The results also show that vocabulary knowledge is not just limited to its usage. Vocabulary use is also important and considered by Schmitt (2010) the ultimate goal without which vocabulary learning and teaching fail.

Furthermore, the results show that the use of new technologies and computer assisted programs can enhance vocabulary learning and teaching. The results of the present study are in line with the studies done in the literature. Carmean and Haefner (2002) believe that new technologies can create an educational environment which is social, active, contextual, engaging and student-owned. They can provide students with ample authentic materials which are not easily accessible in traditional ways. Also, they can increase students' contact and exposure to the language through providing authentic materials that can be reached and worked on at the students' ease (Blake, 2011; Mélodie, 2014). Moreover, language learners can repeatedly see, listen to or watch the materials and vocabulary elements (Brett, 1996).

However, the results of the present study show that the majority of the Iranian EFL learners and teachers do not have enough information about vocabulary notebooks and are against the use of L1 and bilingual dictionaries in vocabulary learning and teaching which is contrary to the ideas put forth by scholars like Nation (2001), Richards and Renandya (2002) and Folse (2004). Nation (2001), for example, based on the studies done in the literature concludes that vocabulary learning is facilitated if the meaning is in learners' first language. It is because L1 meaning has a richer association in the learners' lexicon which can help both short-term and long-term retention of the words. According to Nation (2001), the reason why students and teachers tend to avoid L1 is that students may think "there is a one-to-one correspondence between words in the second language and words in the first language" (p. 304). Learners, therefore, need to be made aware that this is not so by drawing their attention to the underlying meaning of words and the potentials and limits of L1 equivalents (Ivy, 2014). In this connection, scholars like Richards and Renandya (2002) advocate the use of bilingual dictionaries. Bilingual dictionaries are user-friendly and provide appealing information to a wide variety of learners by providing L2 
Amiryousefi, M.

definitions and examples as well as L1 synonyms (Folse, 2004; Amiryousefi \& Vahid, 2010). Setting up a vocabulary notebook is also a valuable practice which can make language learners excited and motivated by reviewing their vocabulary notebooks and seeing how their vocabulary is improving (Nation, 2001; Ledburry, 2007; Amiryousefi \& Vahid, 2010).

\section{References}

Ajzen, I. (1988). Attitudes, personality and behavior. Chicago, IL: Dorsey Press.

Alderson, J. C. (2005). Diagnosing foreign language proficiency: The interface between learning and assessment. New York: Continuum.

Amiryousefi, M., \&Vah id, H. D. (2010). Vocabulary: Challenges and debates. English Language Teaching, 3(3), 89-94. http://dx.doi.org/10.5539/elt.v3n3p89

Augustyn, P. (2013). Translation and bilingual practice for German vocabulary teaching and learning. Unterrichtspraxis/Teaching German, 46(1), 27-43. http://dx.doi.org/10.1111/tger.10127

Baleghizadeh, S., \& Golbin, M. (2010).The effect of vocabulary size on reading comprehension of EFL learners. Linguistic and Literary Broad Research and Innovation, 1(2), 33-46

Banya, K., \& Cheng, M. H. (1997). Beliefs about foreign language learning: A study of beliefs of teachers' and students' cross cultural settings. Paper presented at the Annual Meeting of the Teachers of English to Speakers of Other Languages, Orlando, Florida, USA.

Beck, I., \& McKeown, M. (1985). Teaching vocabulary: Making the instruction fit the goal. Educational Perspectives, 23, 11-15.

Bembenutty, H., \& White, M. C. (2013). Academic performance and satisfaction with homework completion among college students. Learning and Individual Differences, 24, 83-88. http://dx.doi.org/10.1016/j.lindif.2012.10.013

Benjamin, A., \& Crow, J. T. (2010). Vocabulary at the center. Larchmont, NY: Eye on Education.

Bernat, E., \& Gvozdenko, I. (2005). Beliefs about language learning: Current knowledge, pedagogical implications, and new research directions. The Electronic Journal for English as a Second Language, 9(1), 1-21.

Blake, R. (2011). Current trends in online language learning. Annual Review of Applied Linguistics, 31, 19-35. http://dx.doi.org/10.1017/S026719051100002X

Boers, F., \& Lindstromberg, S. (2008). How cognitive linguistics can foster effective vocabulary teaching. In F. Boers \& S. Lindstromberg (Eds.), Cognitive linguistic approaches to teaching vocabulary and phraseology (pp. 1-61). Berlin, Germany: Mouton de Gruyter.

Borg, M. (2001). Teachers' beliefs. English Language Teaching Journal, 55(2), 186-187. http://dx.doi.org/10.1093/elt/55.2.186

Borg, S. (2003). Teacher cognition in language teaching: A review of research on what language teachers think, know, believe, and do. Language Teaching, 36, 81-109. http://dx.doi.org/10.1017/S0261444803001903

Breen, M. P. (Ed.) (2001). Learner contributions to language learning: New directions in research. Harlow, Essex: Pearson Education Limited.

Brett, P. (1996). Using multimedia: An investigation of learners' attitudes. Computer Assisted Language Learning, 9(2-3), 191-212. http://dx.doi.org/10.1080/0958822960090209

Brown, H. D. (2014). Principles of language learning and teaching (6 $6^{\text {th }}$ ed.). White Plains, NY: Pearson Education.

Brown, J. D. (2001). Using surveys in language programs. Cambridge: Cambridge University Press.

Carmean, C., \& Haefner, J. (2002). Mind over matter: Transforming course management systems into effective learning environments. EDUCAUSE Review, 37(6), 27-37.

Ellis, R. (1999). Learning a second language through interaction. Amsterdam, the Netherlands: John Benjamins. http://dx.doi.org/10.1075/sibil.17

Fisherbein, M., \& Ajzen, I. (1975). Beliefs, attitude, intention, and behavior: An introduction to theory and research. Reading, MA: Addition-Wesley. 
Iranian EFL teachers and learners' beliefs about vocabulary learning and teaching

Folse, K. S. (2004). Vocabulary myths: Applying second language research to classroom teaching. Ann Arbor, MI: University of Michigan Press.

Gu, P. Y., \& Johnson, R. K. (1996). Vocabulary learning strategies and language learning outcomes. Language Learning, 46(4), 643-679. http://dx.doi.org/10.1111/j.1467-1770.1996.tb01355.x

Horwitz, E. K., \& Gregersen, T. (2002). Language learning and perfectionism: anxious and non-anxious language learners' reactions to their own oral performance. The Modern Language Journal, 86(4), 562-70. http://dx.doi.org/10.1111/1540-4781.00161

Ivy, A. (2014). Rethinking the role of context and definition in second language vocabulary acquisition (SLVA): An assimilation via a cognitive model of concept formation. International Journal of Research Studies in Language Learning, 3(1), 33-50.

Jones, F. R. (1995). Learning an alien lexicon: A teach-yourself case study. Second Language Research, 11(2), 95-111. http://dx.doi.org/10.1177/026765839501100202

Kagan, D. M. (1992). Implications of research on teacher beliefs. Educational Psychologist, 27(1), 65-90. http://dx.doi.org/10.1207/s15326985ep2701_6

Kim, E. (2008). Beliefs and experiences of Korean pre-service and in-service English teachers about English vocabulary acquisition strategies. Unpublished doctoral dissertation, New York University, New York, NY.

Kitsantas, A., \& Zimmerman, B. J. (2009). College students' homework and academic achievement: The mediating role of self-regulatory beliefs. Metacognition Learning, 4, 97-110. http://dx.doi.org/10.1007/s11409-008-9028-y

Knight, S. (1994). Dictionary use while reading: The effects on comprehension and vocabulary acquisition for students of different verbal activities. The Modern Language Journal, 78, 285-299. http://dx.doi.org/10.1111/j.1540-4781.1994.tb02043.x

Kuntz, P. S. (1996). Beliefs about language learning: The Horwitz model. Retrieved from http://www.eric.ed.gov/PDFS/ED397649.pdf

Laufer, B., \& Hulstijn, J. (2001). Incidental vocabulary acquisition in a second language: The construct of task-induced involvement. Applied Linguistics, 22(1), 1- 26. http://dx.doi.org/10.1093/applin/22.1.1

Ledbury, R. (2007). Vocabulary notebooks. The ILI Language Teaching Journal, 3(1), 63-75.

Li, L., \& Walsh, S. (2011). Seeing is believing: Looking at EFL teachers' beliefs through classroom interaction. Classroom Discourse, 2(1), 32-57. http://dx.doi.org/10.1080/19463014.2011.562657

Macalister, J. (2012). Pre-Service teacher cognition and vocabulary teaching. RELC Journal, 43(1), 99-111. http://dx.doi.org/10.1177/0033688212439312

Maftoon, P. (2012). Relationship between learners' beliefs system and the choice of language learning strategies: A critical study. International Journal of Research Studies in Language Learning, 2(2), 39-48.

Mangubhai, F., Marland, P., Dashwood, A., \& Son, J. B. (2004). Teaching a foreign language: One teacher's practical theory. Teaching and Teacher Education, 20(3), 291- 311. http://dx.doi.org/10.1016/j.tate.2004.02.001

Mélodie, G. (2014). Intentional vocabulary learning from watching DVDs with subtitles: A case study of an 'average' learner of French. International Journal of Research Studies in Language Learning, 3 (1), 21-32.

Milton, J. (2009). Measuring second language vocabulary acquisition.UK: Multilingual Matters.

Mohebi, S. G., \& Khodadadi, E. (2011). Investigating university students' beliefs about language learning. RELC Journal, 42(3), 291-304. http://dx.doi.org/10.1177/0033688211422900

Murray, D. E., \& Christison, M. A. (2011). What English language teachers need to know: Facilitating learning. New York and London: Routledge.

Nation, I. S. P. (2001). Learning vocabulary in another language. Cambridge: Cambridge University Press. http://dx.doi.org/10.1017/CBO9781139524759

Nation, I. S. P., \& Macalister, J. (2010). Language curriculum design. New York, NY: Routledge.

Ng, E. K. J., \& Farrell, T. S. C. ( 2003). Do teachers' beliefs of grammar teaching match their classroom practices? A Singapore case study. In D. Deterding, A. Brown, \& E. L. Brown (Eds.), English in 
Amiryousefi, M.

Singapore: Research on grammar (pp. 128-137). Singapore: McGraw Hill.

Pajares, M. F. (1992). Teachers' beliefs and educational research: Cleaning up a messy construct. Review of Educational Research, 62(3), 307-32. http://dx.doi.org/10.3102/00346543062003307

Read, J. (2004). Research in teaching vocabulary. Annual Review of Applied Linguistics, 24, 146-161. http://dx.doi.org/10.1017/S0267190504000078

Richards, J. C., \& Renandya, W. A. (2002). Methodology in language teaching: An anthology of current practice. New York, NY: Cambridge University Press. http://dx.doi.org/10.1017/CBO9780511667190

Riley, P. (2009). Shifts in beliefs about second language learning. RELC Journal, 40(1)102-124. http://dx.doi.org/10.1177/0033688208101448

Schmitt, N, (2000). Vocabulary in language teaching. Cambridge, UK: Cambridge University Press.

Schmitt, N. (2010). Researching vocabulary: A vocabulary research manual. London, UK: Palgrave Macmillan. http://dx.doi.org/10.1057/9780230293977

Stubbs, M. (1986). Educational linguistics. Oxford, UK: Blackwell.

Tran, T. H. (2011). EFL teachers perceptions about vocabulary acquisition and instruction. Unpublished Doctoral dissertation, Alliant International University, San Diego.

White, C. (1999). Expectations and emergent beliefs of self-instructed language learners. System, 27(4), 443-57. http://dx.doi.org/10.1016/S0346-251X(99)00044-5

Williams, M., \& Burden, R. (1997). Psychology for language teachers. Cambridge: Cambridge University Press. 